\title{
Variables Affected on Economic Performance
}

\author{
Darwin Lie ${ }^{1}$, Arfan Ikhsan ${ }^{2}$, Jubi ${ }^{1}$, Andy Inrawan' ${ }^{1}$ and Hendra Harmain ${ }^{2}$ \\ \{darwinlie@gmail.com,jubi@gmail.com, andyinrawan@gmail.com, hendraharmain@gmail.com\}
}

\author{
${ }^{1}$ STIE Sultan Agung, Indoneisa \\ ${ }^{2}$ Universtias Negeri Medan, Indonesia \\ ${ }^{3}$ Universitas Islam Negeri Sumatera Utara, Indonesia \\ ${ }^{4}$ Universitas Islam Negeri Sumatera Utara, Indoneisa
}

\begin{abstract}
This research aimed to examined some variables affected on economic performance. The variables consist of environmental disclosure (ED), firm size (FS), return on equity (ROE). The population in this research is a 35 non financial company listed on the Indonesian Stock Exchange (ISE). The results conclude that environmental performance (EP), environmental disclosure (ED), firm size (FZ), return on equity (ROE) positively influence on economic performance (EcP).
\end{abstract}

Keywords: economic, environmental, firm, disclosure.

\section{Introduction}

The company's success strategy depends on the quality and integration of information available to decision makers. The way to produce management information such as costs of sales is well establihed, and the systems employed to produce conventional management reports generally ensure timely availability of high-quality data to management. Economic systems based on competition not only realize high allocation efficiency, that is efficiency related to the most effective combination of labor production factors, basic capital. The superiority of the competition system is mainly seen when viewed dynamically as a driver of economic development. However, competitive advantage is gained by generating and capitalizing on business information not generally investigated by one's competitors. Comprehensive management information, including information on environmental costs and opportunities, can yield competitive advantage. (Ikhsan, 2010, p. 5) said that environmental issues direct or not, has been included in the economic performance of a business/activity or organization. (Ferreira, Erasmus and Groenewald, 2004) stated that the issue of environmental conservation is the duty of every individual, government and company. The company has an important role in creating a good and healthy environment. Similiarly, (Djajadiningrat, 2014) said that the world business (company) must play an active role in redefining its operations in a sustainable direction, because without the intervention of the world business, the world as a whole will not be able to succeed in creating sustainable conditions. Therefore, the emphasis of the company's participation in realizing a healthy social and environmental conditions is good.

\section{Overview Teori}

\subsection{The Effect EP on EcP}

The relationship between EP and EcP of firms is an important issue for environmental policy making. (Walley and Whitehead, 1994) stated in the context this relationship, it is often 
stated that there is a conflict between competitiveness of firms and their EP. For example, according to the (Luken, 1997) at the level of a certain industry, the share of environmental costs (EC) in total manufacturing costs might be considerably higher than average. (Clift and Wright, 2000) stated particularly this might be the case for industries upstream in the production chain (such as primary resource extraction or primary manufacturing), which has been proven to cause environmental impacts that are not proportional to the value added associated with their production activities. (Porter, 1991; Porter and Van der Linde, 1995) and Schmidheiny (1992) stated only recently, the idea of increasing environmental performance is a potential source of competitive advantage because it can lead to more efficient processes, increased productivity, lower compliance costs and new market opportunities, although this often refers to other aspects of EP than those addressed and measured traditionally (Wehrmeyer and Tyteca, 1998). Therefore, the preceding arguments lead to the first hypothesis:

$\mathrm{H} 1=$ The EP has influence on EcP

\subsection{The Effect of ED on EcP}

Corporate Environmental Disclosure (CED) refers to "accountability to society as a whole with respect to matters of public interest such as community welfare, public safety, and the environment" (Radebauh and Gray, 2002; Mahmes, 2016). According to (Arevalo and Aravind, 2011) to justify its continued existence, a firm should be held accountable for its performance and actions that impact upon people, their communities and their environment; to create a channel of communication with the community and legitimize its behavior and attitude towards the community in which it operates (Deegan and Rankin, 1996). The relevance of ED derives from the fact that the most of information on CED is financial and quantitative in nature, and it can have a direct impact on the financial and $\mathrm{EcP}$ of the corporation (Marston and Shrives, 1991). Therefore, it should be noted that the environment responsibility does not require the company to abandon other main operations. According to (Gerbens-Leenes, Moll and Schoot Uiterkamp, 2003) however, the ECP of business enterprises is often considered in correlation with its social and ED. Based on the explanation, the second hypothesis of this research is as follows:

$\mathrm{H} 2=$ The $\mathrm{ED}$ has influence on $\mathrm{EcP}$

\subsection{The Effect of FS on EcP}

According to Bayyurt (2007) and (Doğan, 2013)big companies have more competitive strength compared to smaller companies in fields that require competition. Because they have a larger market share, big companies have more profit opportunities. In addition, big companies can take advantage of opportunities to work in fields that require high levels of capital because they have more resources, and this situation gives them the opportunity to work in more profitable fields with little competition. When the studies focus the relation between FS and profitability are reviewed, mixed results have been found present. (Majmudar, 1997)found the impact that FS has on firm probability and productivity with a sample of 1020 Indian firms. While controlling for other variables that may affect firm performance, the study found evidence that bigger firms are less productive but more profitable. (Doğan, 2013)stated some result previous researh (like Hall and Weiss, 1967; Fiegenbaum and Karnani, 1991; (Majmudar, 1997); Özgülbaş et al. 2006; Jonsson, 2007; Serrasqueiro and Nunes 2008; Lee, 2009; Stierwald, 2009; Karadeniz and İskenderoğlu, 2011; Saliha and Abdessatar, 2011; Akbaş and Karaduman, 2012; Shubita and Alsawalhah, 2012) have found a positive relation 
between FS and profitability. Based on the explanation, the third hypothesis of this research is as follows:

$$
\mathrm{H} 3=\text { FS has influence on EcP }
$$

\subsection{The Effect of ROE on EcP}

According to (Purnamasari, 2015), ROE is an analysis commonly used by investors and company leaders, to measure how much profit can be the right owner's own capital. For investors, the analysis of ROE is important because the analysis can determine the benefits of the investments made. For firm, this techniques is important because it is a pull factor for investors to invest. ROE is a measure of earnings (income) are available for the owners of the firm (both ordinary shareholders and preferred shareholders) on the capital they invest in the firm. Commonly, the higher return or income earned, the better position of the firm owner. ROE shows the profitability of own capital or often referred to as the profitability of the business. Based on the explanation, the fourth hypothesis of this research is as follows:

$\mathrm{H} 4=$ Return on equity has influence on economic performance

\section{Research Methods}

Non financial Indonesian companies listed on the Indonesian Stock Exchange (ISE) are the sample population of this study. The sample companies are choice based on some selection criteria. First, firm must listed on the Indonesian Stock Exchange after 1 January 2012. Second, firm not delisting during research. Third, company must publish their financial report audited during 2012-2014. Secondary data chosen as the source data, whereas the sources of the data indirectly obtained through intermediary media (Ikhsan, 2011). There are many advantages in using secondary data since the data gathered are less expensive, faster, and easier to obtain compared primary data.

To analyze the data, we use some technical in classical assumtion such as test of normality, multicolinearity, autocorelation and heteroskedasticity. The result shows that model is normal and free from multicolinearity, autocorelation and heteroskedasticity. To test hypothesis from $\mathrm{H} 1$ to H4, we use statistical multiple regression analysis. The multiple regression analysis model used in this study is shown in the following formula:

$\mathrm{EcP}=\alpha+\beta 1 \mathrm{EP}+\beta 2 \mathrm{ED}+\beta 3 \mathrm{FS}+\beta 4 \mathrm{ROE}+\varepsilon$

\section{Result And Discussion}

\subsection{Descriptive Analysis}

The purpose of the variable description is to provide a brief overview of the research variables. Description of research variables described using the minimum, maximum, and mode of each variable. The minimum, maximum, and mode values of each variable are based on data from companies listed on the ISE during 2012-2014. Some of the variables in this study were measured using more than one indicator based on previous research and other relevant refrentions. Table 1 presents the results of research data processing that results in minimal, maximum, and mode values of the research variables.

Table 1. Descriptive Statistics

\begin{tabular}{lccccc}
\hline & $\mathrm{N}$ & Min & Max & Mean & $\begin{array}{c}\text { Std. } \\
\text { Deviation }\end{array}$ \\
\hline Ecp $(\mathrm{Y})$ & 105 &,- 76082 & 1,45396 &, 0307221 &, 30018982 \\
\hline
\end{tabular}




\begin{tabular}{lrrrrr}
\hline Enp (X1) & 105 & 1,00000 & 5,00000 & 3,2666667 &, 82353211 \\
\hline End (X2) & 105 &, 03333 &, 90000 &, 2965079 &, 29092184 \\
\hline Size (X3) & 105 & 26,61265 & 32,03368 & 29,60618 & 1,2844632 \\
\hline Roe (X4) & 105 &,- 56844 & 1,25806 &, 1623671 &, 25740723 \\
\hline Valid & 105 & & & & \\
N(listwise) & & & & & \\
\hline
\end{tabular}

Source: Ouput SPSS

\subsection{Multiple Regression Analysis (MRA)}

Table 2. Multiple Regression Analysis Test Coefficientsa

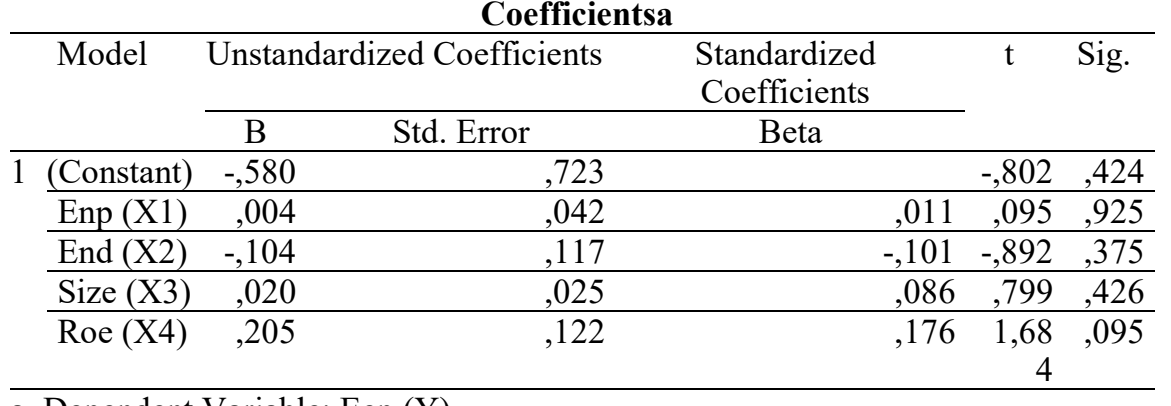

a. Dependent Variable: Ecp (Y)

Source: Ouput SPSS

The result of the test multiple regression analysis in table 2 conclude accepted hyphotesis 1 (H1). Threfore, we conclude that environmental performance (X1) positively influence on economic performance (Y). This is consistent with the result obtained (Al-Tuwaijri, Christensen and Hughes, 2004), also (Heriningsih and Saputri, 2015) and not consistent with (Sarumpaet, 2006), also (Almilia and Herdinigtyas, 2005) also (Rakhiemah and Agustia, 2009) finding. The result of the hyphotesis 2 (H2) in table 2 conclude accepted hyphotesis 2 (H2). Therefore, we conclude that environmental performance (X2) positively influence on economic performance (Y). This is consistent with the result obtained (Lindrianasari, 2007) and not consistent with (Almilia and Herdinigtyas, 2005) finding. The result of the hyphotesis 3 (H3) in table 3 conclude accepted hyphotesis 3 (H3). Therefore, we conclude that firm size (X3) positively influence on economic performance (Y). This is consistent with the result obtained (Fachrudin, 2011) and not consistent with (Sunarko and Astuti, 2012; Hasnawati and Sawir, 2015) finding. The result of the hyphotesis 4 (H4) in table 2 conclude accepted hyphotesis $4(\mathrm{H} 4)$. Therefore, we conclude that return on equity (X4) positively influence on economic performance (Y). This is consistent with the result (Herdiana, 2003) and not consistent with (Hutami, 2012; Carlo, 2014) finding.

Table 3. F-test

\begin{tabular}{|c|c|c|c|c|c|c|}
\hline \multicolumn{7}{|c|}{ ANOVAb } \\
\hline & Model & $\begin{array}{l}\text { Sum of } \\
\text { Squares }\end{array}$ & Df & $\begin{array}{l}\text { Mean } \\
\text { Square }\end{array}$ & & Sig. \\
\hline 1 & Regression & ,478 & 4 & ,119 & $\begin{array}{r}1,34 \\
3\end{array}$ & $\begin{array}{r}260 \\
\mathrm{a}\end{array}$ \\
\hline & Residual & 8,894 & 100 &, 089 & & \\
\hline & Total & 9,372 & 104 & & & \\
\hline
\end{tabular}




\begin{tabular}{|c|c|c|c|c|}
\hline \multicolumn{5}{|c|}{ ANOVAb } \\
\hline & $\begin{array}{l}\text { Sum of } \\
\text { Squares }\end{array}$ & Df & $\begin{array}{l}\text { Mean } \\
\text { Square }\end{array}$ & $\begin{array}{ll} & \text { Sig. } \\
\end{array}$ \\
\hline \multirow[t]{3}{*}{$\mathbf{1}$} & Regression & 4 & ,119 & $\begin{array}{rr}1,34,260 \\
3 \quad \mathrm{a} \\
\end{array}$ \\
\hline & Residual & 100 & 089 & \\
\hline & 9,372 & 104 & & \\
\hline & $\begin{array}{l}\text { edictors: (Constant), Roe } \\
\text { X1) } \\
\text { pendent Variable: Ecp (Y) }\end{array}$ & (X4 & nd (X2), & ze (X3), \\
\hline
\end{tabular}

Source: Ouput SPSS

Table 3 shows F-test value are 1,343 with F probability are 0,260, this valeu more than $\alpha$ $5 \%(0,05)$, it means all the variables not affected as significant between EP, ED, FS, ROE on EcP.

Table 4. Coefficient Determination Test

\begin{tabular}{|c|c|c|}
\hline \multicolumn{3}{|c|}{ Model Summaryb } \\
\hline$\overline{\text { Model }}$ & $\begin{array}{c}\text { R Square Adjusted } \\
\text { Square }\end{array}$ & $\begin{array}{l}\text { R Std. Error of the } \\
\text { Estimate }\end{array}$ \\
\hline 1 & ,26a ,051 & 29823190 \\
\hline
\end{tabular}

Source: Ouput SPSS

In Table 4, the coefficient determination test indicates that adjusted $R$ square values are 0,013 , which means that the variation rate of the EP, ED, FS, ROE variables can be explained by the EcP variables are $1,3 \%$. While the rest $98,7 \%$ is explained by other variables outside the proposed model.

\section{Conclusions}

With the general objective to identify characteristics related to economic performance. First, we conclude that environmental performance (X1) positively influence on economic performance (Y). Second, we conclude that environmental performance (X2) positively influence on economic performance (Y). Third, we conclude that firm size (X3) positively influence on economic performance $(\mathrm{Y})$. Fourth, we conclude that return on equity (X4) positively influence on economic performance $(\mathrm{Y})$.

\section{References}

[1] Al-Tuwaijri, S. A., Christensen, T. E. and Hughes, K. . (2004) 'The relations among environmental disclosure, environmental performance, and economic performance: a simultaneous equations approach', Accounting, Organizations and Society. Pergamon, 29(5-6), pp. 447-471. doi: 10.1016/S0361-3682(03)00032-1.

[2] Almilia, L. S. and Herdinigtyas, W. (2005) 'Analisis Rasio Camel Terhadap Prediksi Kondisi Bermasalah Pada Lembaga Perbankan Perioda 2000-2002', Jurnal Akuntansi dan Keuangan, 7(2), pp. 131-147. Available at: http://puslit2.petra.ac.id/ejournal/index.php/aku/article/view/16448.

[3] Arevalo, J. A. and Aravind, D. (2011) 'Corporate social responsibility practices in India: approach, drivers, and barriers', Corporate Governance: The international 
journal of business in society. Edited by G. Lenssen. Emerald Group Publishing Limited, 11(4), pp. 399-414. doi: 10.1108/14720701111159244.

[4] Carlo, M. A. (2014) 'Pengaruh Return On Equity, Dividend Payout Ratio, dan Price to Earning Ratio pada Return Saham', E-jurnal Akuntansi Universitas Udayana, 7.1(Januari), pp. 151-164. doi: 10.1017/CBO9781107415324.004.

[5] Clift, R. and Wright, L. (2000) 'Relationships Between Environmental Impacts and Added Value Along the Supply Chain', Technological Forecasting and Social Change. North-Holland, 65(3), pp. 281-295. doi: 10.1016/S0040-1625(99)00055-4.

[6] Deegan, C. and Rankin, M. (1996) 'Do Australian companies report environmental news objectively?’, Accounting, Auditing \& Accountability Journal. MCB UP Ltd, 9(2), pp. 50-67. doi: 10.1108/09513579610116358.

[7] Djajadiningrat, S. T. (2014) Green Economy. Bandung: Rekayasa Sains.

[8] Doğan, M. (2013) 'Does Firm Size Affect The Firm Profitability? Evidence from Turkey', Research Journal of Finance and Accounting, 4(4), pp. 53-60. doi: 10.5539/ibr.v5n9p120.

[9] Fachrudin, K. A. (2011) 'Analisis Pengaruh Struktur Modal, Ukuran Perusahaan, dan Agency Cost Terhadap Kinerja Perusahaan', Jurnal Akuntansi dan Keuangan, 13(1), pp. 37-46. doi: 10.9744/jak.13.1.37-46.

[10] Ferreira, E., Erasmus, A. and Groenewald, D. (2004) Administrative Management. Lansdowne.

[11] Gerbens-Leenes, P. ., Moll, H. . and Schoot Uiterkamp, A. J. . (2003) 'Design and development of a measuring method for environmental sustainability in food production systems', Ecological Economics. Elsevier, 46(2), pp. 231-248. doi: 10.1016/S0921-8009(03)00140-X.

[12] Hasnawati, S. and Sawir, A. (2015) 'Keputusan Keuangan, Ukuran Perusahaan, Struktur Kepemilikan dan Nilai Perusahaan Publik di Indonesia', Jurnal Manajemen dan Kewirausahaan (Journal of Management and Entrepreneurship), 17(1), pp. 65-75. doi: 10.9744/jmk.17.1.65-75.

[13] Herdiana, D. F. (2003) Analisis Pengaruh Informasi Akuntansi terhadap Return Saham di Bursa Efek Jakarta. UNiversitas Diponegoro.

[14] Heriningsih, S. and Saputri, N. (2015) 'PENGARUH CORPORATE SOCIAL RESPONSIBILITY DISCLOSURE DAN ENVIRONMENTAL PERFORMANCE TERHADAP ECONOMIC PERFORMANCE PADA PERUSAHAAN MANUFAKTUR YANG TERDAFTAR DI BURSA EFEK INDONESIA', Jurnal Ekonomi Dan Bisnis. Available at: http://onesearch.id/Record/IOS1354.article-337 (Accessed: 22 January 2019).

[15] Hutami, R. P. (2012) 'Pengaruh Dividend Per Share, Return on Equity dan Net Profit Margin Terhadap Harga Saham Perusahaaan Industri Manufaktur yang Tercatat di Bursa Efek Indonesia Periode 2006-2010', Nominal, Barometer Riset Akuntansi dan Manajemen, 1(2). doi: 10.21831/NOMINAL.V1I2.1001.

[16] Ikhsan, A. (2010) Akuntansi Keperilakuan. Jakarta: Salemba Empat.

[17] Ikhsan, A. (2011) Pengaruh Faktor Kualitas Audit terhadap Kepuasan Klien: Opini Audit Going Concern sebagai Variabel Pemoderasi. Universitas Brawijaya.

[18] Lindrianasari, L. (2007) 'Hubungan antara kinerja lingkungan dan kualitas pengungkapan lingkungan dengan kinerja ekonomi perusahaan di Indonesia', JAAI, 11(2), pp. 159-172.

[19] Luken, R. (1997) 'The effect of environmental regulations on industrial competitiveness of selected industries in developing countries', Greener Management International, pp. 67-78. 
[20] Mahmes, K. (2016) 'Corporate Environmental Disclosure and Economic Performance of Companies in the Libyan Manufacturing Sector', International Journal of Economics and Finance Studies, 8(2), pp. 1309-8055. Available at: http://www.sobiad.org/ejournals/journal_ijef/archieves/IJEF-2016_2/kemal.pdf.

[21] Majmudar, S. K. (1997) 'The Impact of Size and Age on Firm-Level Performance: Some Evidence from India', Review of Industrial Organization. Kluwer Academic Publishers, 12(2), pp. 231-241. doi: 10.1023/A:1007766324749.

[22] Marston, C. L. and Shrives, P. J. (1991) 'The use of disclosure indices in accounting research: A review article', The British Accounting Review. Academic Press, 23(3), pp. 195-210. doi: 10.1016/0890-8389(91)90080-L.

[23] Porter, M. E. (1991) 'America's Green Strategy', Scientific American, 264(4). Available at: https://www.hbs.edu/faculty/Pages/item.aspx?num=6107 (Accessed: 22 January 2019).

[24] Porter, M. E. and Van der Linde, C. (1995) 'Green and Competitive: Ending the Stalemate', Harvard Business Review, 73(5). Available at: https://hbr.org/1995/09/green-and-competitive-ending-the-stalemate (Accessed: 22 January 2019).

[25] Purnamasari, D. (2015) 'he Effect of Changes in Return on Assets, Return on Equity, and Economic Value Added to the Stock Price Changes and Its Impact on Earnings Per Share', Research Journal of Finance and Accounting. International Institute for Science, Technology \& Education, 6(6), pp. 80-89. Available at: https://www.iiste.org/Journals/index.php/RJFA/article/view/21162 (Accessed: 22 January 2019).

[26] Radebauh, L. H. and Gray, S. J. (2002) International Accounting and Multinational Enterprises. New York, NY: John Wiley \& Sons, Ltd.

[27] Rakhiemah, A. N. and Agustia, D. (2009) 'Pengaruh Kinerja Lingkungan Terhadap Corporate Social Responsibility (CSR) Disclosure dan Kinerja Finansial Perusahaan Manufaktur Yang Terdaftar di Bursa Efek Indonesia', in Seminar Nasional Akuntansi 12. Palembang. Available at: http://blog.umy.ac.id/ervin/files/2012/06/akmk29.pdf (Accessed: 22 January 2019).

[28] Sarumpaet, S. (2006) 'The Relationship Between Environmental Performance And Financial Performance of Indonesian Companies', Jurnal Akuntansi dan Keuangan, 7(2), pp. 89-98. doi: 10.9744/JAK.7.2.PP. 89-98.

[29] Sunarko, M. R. and Astuti, D. S. P. (2012) 'Rasio Keuangan Dan Kinerja Perusahaan', Explorasi, 14(1), pp. 101-109. Available at: https://www.ejurnal.unisri.ac.id/index.php/Exsplorasi/article/viewFile/298/260 (Accessed: 22 January 2019).

[30] Walley, N. and Whitehead, B. (1994) 'It's Not Easy Being Green', Harvard Business Review, pp. 46-52. Available at: https://hbr.org/1994/05/its-not-easy-being-green (Accessed: 22 January 2019). 